\title{
David Williams
}

\section{Pod powierzchnią świata, poza historią - ku kontrhistorii odpadów i ziemi jałowej ${ }^{1}$}

\begin{abstract}
Williams David, Pod powierzchnią świata, poza historią - ku kontrhistorii odpadów i ziemi jałowej [Underworld, underground, underhistory. Towards a counterhistory of waste and wastelands]. "Przestrzenie Teorii" 15. Poznań 2011, Adam Mickiewicz University Press, pp. 259-281. ISBN 978-83-232-2293-4. ISSN 1644-6763.
\end{abstract}

The article is a collage of texts concerning the phenomena of waste in context underworld, underground and underhistory. Starting from environmentalism, cultural studies, sociology and psychoanalysis, the author moves towards a wide array of contemporary art practices. 'Garbage', 'trash', 'refuse', 'waste' and 'rubbish' are presented as complex and ambivalent metaphorical terms employed to organize and legitimize the parts of life normally desired to be overlooked. Waste: the excessive remainder of production and consumption, detritus of that which is deemed 'use-less' in 'progress'; the informe material that has been reappropriated and recycled in countless artworks since the collages of Cubism, Dada and Surrealism's détournements of objets trouvés. The author goes deeper: in order to present a global consciousness, he introduces a spectrum of artists and art works concerned with waste's constitutive presence in and implications for contemporary landscapes, both literal and cultural. His description includes land artists, environmental artists, activists and conceptualists, such as Alan Sonfist, Agnes Denes, Agnès Varda, Edward Burtynsky, Maurizio Cattelan, and Mierle Laderman Ukeles.

\section{Gdzieś / tu (1): sieć widmo}

Gdzieś tam, tak daleko / tak blisko sieć widmo dryfuje pod powierzchnia oceanu. Widziana $z$ dystansu wydaje się unoszaca się $w$ toni wyspa albo mata, tnaca powierzchnię wody rafa. Jednak z bliska, kiedy

${ }^{1}$ Niniejszy kolaż tekstów napisany został z inspiracji rosnącego zainteresowania odpadami nie tylko $\mathrm{w}$ dyskusjach związanych $\mathrm{z}$ ochroną środowiska, ale również $\mathrm{w}$ nauce o kulturze, archeologii, socjologii, psychologii i psychoanalizie, a także częstego ich użycia przez współczesnych artystów. Doprowadziła mnie do niego także długoletnia obserwacja wpływu zglobalizowanych korporacji i zorganizowanego świata przestępczego na obieg materii. Jej cyrkulacja prowadzi do tworzenia nowych zjawisk przyrodniczych, jakimi są rozległe, pełne odpadów, toksyczne krajobrazy. Wreszcie bezpośrednią inspiracją do napisania tego tekstu były rozmowy z kolegami i studentami, a także dyskusje, które toczyliśmy m.in. na konferencji Landscape and Environment („Krajobraz i środowisko”, odbywającej się w czerwcu 2009 na Uniwersytecie Aberystwyth w Walii (koordynatorzy - prof. Mike Pearson i dr Heike Roms). Powiązane tematycznie teksty, które uznać można za część tego samego projektu, publikowałem w Wielkiej Brytanii m.in. na łamach "Performance Research" 2010, r. 15, nr 4, s. 131-140. 
dostrzec można gromadzony mimochodem połów, opowiada odmienna historię. Wśród łupu rozpoznać można pochwycone wodorosty, kawatki drewna, sznurki i żytki; zgniecione puszki po napojach, a między nimi puszkę, w której zostało jeszcze troche toksycznej mazi; opakowania po chipsach, plastykowe butelki, pojemnik po aerozolu. Martwe ryby, ciała ptaków różnych gatunków i korpus młodego delfina. A także trzepoczaca jeszcze skrzydtami mewę, której noga wtaśnie zaplatała się w nylonowe włókna. Jej ruch to jedyny zauważalny znak życia.

Floty rybackie na petnym morzu działają często na granicy prawa. Chętnie używają dryfujących sieci, które - jeśli zerwa się z uwięzi - rozpoczynaja swobodna lewitacje $w$ wodzie. Tak inicjowana jest śmiertelna, nigdy niekończaca się odyseja. Kilkukilometrowe dryfujace pułapki więża wszystko, cokolwiek będzie miało nieszczęście znaleźć się $w$ ich polu rażenia. Zapetniaja się, dopóki ciężar śmieci i rozkładajacych się zwierząt nie ściagnie ich na dno.

Kiedy osiąda, organiczne szczątki rozktadaja sie pierwsze, pozwalając, by sieć widmo mogta znów unieść się $w$ toni. Wyptywa na powierzchnię, a caty cykl zaczyna sie od początku. Czas jego trwania trudno mierzyć, stosując miary stońca, faz księżyca czy cierpliwego pulsu oceanu, $z$ jego przyplywami $i$ odplywami, dawaniem i odbieraniem. Może trwać $w$ nieskończoność.

\section{Cienie historii}

Śmieci, odpadki, odrzuty czy nieczystości to słowa o złożonych sensach, ambiwalentne i metaforyczne. Wieloznaczność tych i podobnych im określeń pozwala na używanie ich w celu organizowania i sankcjonowania sposobu, w jaki traktowane są te spośród elementów rzeczywistości, które planowo mają zostać przeoczone ${ }^{2}$. Jako zbyteczne produkty wytwarzania i konsumpcji są odrzucane na wszystkich etapach planowego porządkowania. Jeśli produkuje się zbyt wiele i ponad miarę konsumuje, na uboczu zawsze pozostaje materia dla postępu „zbędna”. To kłopotliwe resztki, szczątki, bezforemne produkty rozkładu.

Kiedy spojrzymy na burzliwy, zasnuty czarnymi chmurami świat z perspektywy opisanego przez Waltera Benjamina ${ }^{3}$, zwróconego plecami

2 Zjawisko to, między innymi autorami, omawiają John Scanlan i Zygmunt Bauman.

3 „Klee namalował obraz, zatytułowany Angelus Novus. Przedstawia anioła, który wygląda, jak gdyby chciał się oddalić od czegoś, w co się uporczywie wpatruje. Oczy szeroko rozwarte, usta otwarte, skrzydła rozpięte. Tak musi wyglądać anioł historii. Zwrócił 
ku przyszłości anioła historii, zrozumiemy rodzącą się już w świadomości autora Pasaży konieczność myślenia o odpadkach - niechcianych i odpychanych „żywych trupach kapitalizmu"4. Zainteresowanie nimi, a nawet samo tylko - błahe z pozoru - zwrócenie na nie uwagi, wywoływać może osobliwe duchy minionych historii i miejsc, cienie przeszłości, „rzeczy, ludzi i działań pozbawionych wartości i odrzuconych"5.

Historia każdej rzeczy (również historia jej społecznego funkcjonowania i użycia) pogrzebana zostaje pod banalnością znaczeniową odpadu, jakim się staje. Nazwana śmieciem traci, w perspektywie biopolityki i hierarchizacji, wartość materialną i kulturową. Niewyróżniona z masy innych śmieci, wyrzucona zostaje za granice obszaru jakiegokolwiek zainteresowania. Odpady, jako „nadliczbowe i zbędne”, stają się niezauważalne, ale uwolnić się od nich trudno. W najmniej spodziewanych momentach wyłaniają się spoza marginesu uwagi, a kiedy wracają, niosą już inne, od pierwotnych, sensy. Jakim procesom, dzięki którym ten etap ich historii przeciwny jest jej typowemu biegowi, zostają poddane? Czy zabiegi te mogą być podobne rutynie opisanej przez Dona DeLillo jako część dyskusji nad pośrednictwem języka $\mathrm{w}$ granicach opozycyjnych, ideologicznie nacechowanych dyskursów? Praktyka ta określona została jako „kontrhistoryczny sposób odkupienia przez język”. Zgodnie z jej objaśnieniem, to język właśnie staje się „pośrednikiem spłaty, paradoksalnie dostarczającym pozytywnych wartości jako rezultat konceptualnego przekształcenia bezlitośnie płaskiego, wąskiego i ciasnego wzorca historycznego"7.

oblicze ku przeszłości. Gdzie nam ukazuje się łańcuch zdarzeń, on widzi jedną wieczną katastrofę, która nieustannie piętrzy ruiny na ruinach i ciska mu pod stopy. Chciałby zatrzymać się, zbudzić umarłych i złączyć to, co rozbite. Ale od raju wieje wicher, który napiera na skrzydła i jest tak silny, że anioł nie może ich złożyć. Ten wicher pędzi go niepowstrzymanie w przyszłość, do której jest zwrócony plecami, podczas gdy przed nim rośnie stos ruin. Tym wichrem jest to, co nazywamy postępem” (W. Benjamin, Aniot historii. Eseje, szkice, fragmenty, red. H. Orłowski, przeł. K. Krzemieniowa i in., Poznań 1996, s. 419).

${ }_{4}$ S.Ch. Dickson, Says the junk in the yard (katalog wystawy), London 2007 (strony nienumerowane).

5 J. Scanlan, On Garbage, London 2005, s. 10.

${ }^{6}$ Z. Bauman, Życie na przemiat, przeł T. Kunz, Kraków 2004, s. 13.

7 D. DeLillo, The Power of History, "New York Times" 7 September 1997. Ten odwrócony bieg historii zarysowany został przez Michela Foucaulta w serii jego wykładów w Collège de France z roku 1976, rozważających pojawienie się odmiennych i opozycyjnych dyskursów, które odkrywają, ujawniają i uwidaczniają utajone historie i pamiątki przeszłości (M. Foucault, Trzeba bronić społeczeństwa. Wykłady w Collège de France, 1976, przeł. M. Kowalska, Warszawa 1998). 


\section{Leonia}

Nic nie znika bezpowrotnie. Zazwyczaj zmienia tylko formę. Śmieci sa nieśmiertelne, przenikaja atmosferę, unosza się w wodzie, rozpuszczaja się, gnija, rozpadaja się, zmieniaja w gaz, dym, sadze; podróżuja po świecie, stopniowo go zalewajac ${ }^{8}$.

Leonia jest tym z Niewidzialnych miast Itala Calvina, które ogarnięte jest wszechobecną ekonomią rozwiązłej konsumpcji. Z nią powiązany jest odwieczny problem odpadów. Skoro wszystkie dobra można postrzegać jako „przyszłe śmieci”, dystans pomiędzy nowością a wyjściem z użycia podlega drastycznemu skurczeniu, dążąc do „skondensowanej archeologii"10. Wszystko może „wyjść z mody jednego dnia”, każda rzecz może zostać - z dnia na dzień, gdy pojawi się nowa - porzucona. Nie ma pewności czy „prawdziwa namiętność” Leonii to „radość z nowych i odmiennych przedmiotów", czy raczej odrzucanie, wydalanie, obmywanie się z narastającej nieczystości”"11.

Ludzie sprzątający ulice, których każdego dnia „przyjmuje się jak aniołów”, usuwają „pozostałości wczorajszej egzystencji”, ale nikt nie wie, dokąd je zabierają: pewnie gdzieś na zewnątrz miasta, poza nie. Tam masa odpadów wciąż przyrasta, ich stosy odkładają się, nawarstwiają i wznoszą się wciąż wyżej i wyżej. W końcu „forteca niezniszczalnych resztek otacza Leonię ze wszystkich stron, piętrzy się nad nią jak zespół płaskowyży”12. „Skutek jest taki: im więcej Leonia wydala, tym więcej gromadzi. Łuski jej przeszłości spajają się w pancerz nie do zdjęcia; odnawiając się codziennie, miasto zachowuje się całe w jedynym ostatecznym kształcie: wczorajszych śmieci, które piętrzą się na śmieciach z przedwczoraj i ze wszystkich jego dni i lat i dziesiątków lat"13.

W tym samym czasie i inne miasta „odpychają jak najdalej od siebie góry odpadków. Może cały świat, poza granicami Leonii, jest pokryty kraterami śmieci, z których każdy ma pośrodku metropolię w ciągłej erupcji. Granice między obcymi i wrogimi miastami - to zapowietrzone bastiony, w których ich szczątki podpierają się wzajemnie, nakładają, mieszają"14.

8 I. Klima, Love and Garbage, trans. E. Osers, London 1999, s. 6.

9 J. Stallabrass, Trash, [w:] The Object Reader, eds F. Candlin, R. Guins, London 2009, s. 406.

10 Tamże, s. 416.

11 I. Calvino, Niewidzialne miasta, przeł. A. Kreisberg, Kraków 2004, s. 96.

12 Tamże, s. 97.

13 Tamże.

14 Tamże. 


\title{
Campania Felix: krajobrazy ekomafii
}

\author{
Brałem go za rękę i ciagnątem do okna. \\ „Patrz! Tam! Na zboże, co rośnie! tam! \\ Patrz! Na te żagle todzi rybackich! \\ Wyptywają na połów sardynek. Na całe to piękno!" (Pauza) \\ Wyrywat mi swoja rękę $i$ wracat do swego kata. \\ Przerażony. Widziat tylko popioły ${ }^{15}$.
}

Od mniej więcej dwudziestu pięciu lat wyraźnie zauważalny jest wzrost szczególnego rodzaju przestępczości, powiązanej z nielegalnym składowaniem odpadów. Proceder ten, którego początki sięgają końca lat siedemdziesiątych, generuje tak wielkie dochody, że niepodzielnie panują nad nim organizacje przestępcze. Sa one określane mianem ekomafia. Gangsterskim formom kapitalizmu obojętne są zgubne skutki rozprowadzania toksycznych odpadów. Jeden z przywódców sycylijskiej Cosa Nostry, aresztowany w 2006 roku Bernardo Provenzano, w jednym z grepsów z celi miał dosadnie wytłumaczyć ten mechanizm: „to proste stwierdził - pozbywamy się gówna, a wraca do nas złoto”. Włoscy śledczy wskazują, że każdego roku miliony ton odpadów przemysłowych, z czego około 300000 ton jest silnie toksycznych, po prostu „znika”. Ich drogi nie sposób prześledzić. Szacuje się, że w samej prowincji Mediolan każdego dnia przepada bez śladu około 500 ton odpadów, co stanowi około $40 \%$ wszystkich wytwarzanych tam śmieci.

Epicentrum nielegalnego składowania śmieci znajduje się w sercu włoskiej Kampanii. Obszar ten historycznie nazywany jest Campania Felix (Szczęśliwy Kraj), a reklamujące go slogany na turystycznych tablicach mówią, że to „ziemia tak czysta jak światło dnia”. W turystycznej promocji wykorzystywany jest też cytat z pism Pliniusza Starszego, który niemal 2000 lat temu stwierdził: „Ziemia ta jest tak radosna, tak zachwycająca i szczęśliwa, że oczywiste wydaje się, że musi być ulubienicą Natury. Ożywcze powietrze, wiecznie czyste niebo, urodzajna gleba [...]". Na początku XXI wieku coś się zmieniło. Na północnych krańcach aglomeracji Neapolu, w obszarze tak zwanej „ognistej ziemi”, znajduje się dzisiaj największe w całej Europie Zachodniej skupisko nielegalnych wysypisk i spalarni śmieci, również toksycznych. Szacunkowy przyrost odpadów składowanych $\mathrm{w}$ tym rejonie przez ostatnich kilka lat to około miliarda ton rocznie. Efektem jest zatruta ziemia i zatrutych wielu jej mieszkańców.

15 S. Beckett, Końcówka, [w:] tegoż, Dramaty. Wybór, przeł. A. Libera, Wrocław 1999, s. 143. 
Zgodnie $\mathrm{z}$ raportami Lagambiente ${ }^{16}$,jeśli na obszarze trzech hektarów zebrano by wszystkie śmieci, które od początku lat dziewięćdziesiątych ominęły we Włoszech legalne procedury, powstałby w ten sposób sześcian wysokości 14600 metrów. Mont Blanc wznosi się na 4810 metrów nad poziom morza, Mount Everest ma 8850 metrów. Zatem stos nieuregulowanych niczym i niekontrolowanych odpadów byłby najwyższą górą na Ziemi"17.

Niemal wszystkie śmieci pochodzące z północy Włoch transportowane są na południe kraju, co pociąga za sobą koszty o 40 do 80 procent mniejsze niż ich legalna utylizacja. Przywiezione odpady składowane są na terenie Kampanii, Kalabrii, Apulii i Sycylii. Regiony te, jak wskazuje Roberto Saviano, to obszary o największej odnotowywanej liczbie przestępstw związanych ze środowiskiem naturalnym. Jako znaczący odbierać można także fakt, że mają one stałe miejsce w czołówce statystyk dotyczących działalności grup przestępczych, bezrobocia i największej liczby ochotników zgłaszających się do wojska i policji18.

Wśród odrzutów znaleźć można wszystkie rodzaje materii, której chciano się pozbyć: pozostałości wygarnięte z pieców do spalania odpadów, azbest, zatrutą ziemię zebraną z terenów oczyszczanych, odpady petrochemiczne, pozostałości farb, rozcieńczalniki chemiczne, rakotwórcze wodorowęglany, odpady radioaktywne i szpitalne, stare nawierzchnie dróg z wysoką zawartością smoły, chemiczny szlam z garbarni, muł z oczyszczalni ścieków zawierający metale ciężkie: ołów, rtęć, kadm (także arsen, chrom, nikiel, kobalt), a nawet ekshumowane szczątki ludzkie pochodzące ze starych cmentarzy, które zgodnie z prawem mogły zostać „oczyszczone”, jeśli ostatnie pochówki odbyły się na nich co najmniej czterdzieści lat wcześniej. Powstałe w ten sposób nowe warstwy geologiczne urozmaicane są przez smugi sadzy i popiołów z nielegalnego spalania. Obecne w nich duże ilości dioksyn zatruwają ludzi, łatwo znajdując drogę na ich stoły poprzez pitną wodę czy mozzarellę z bawolego i krowiego mleka19.

Roberto Saviano opisał przypadek rolnika, który podczas orki nowo zakupionego pola natrafił na pulpę rozkładających się banknotów jedno-

${ }^{16}$ Lagambiente - utworzona w 1980 roku włoska organizacja pozarządowa zajmująca się problemami środowiska, która jako pierwsza, w latach dziewięćdziesiątych, zastosowała określenie ekomafia (przyp. tłum.).

${ }^{17}$ Cyt. za R. Savino, Gomorrah: Italy's Other Mafia, trans. V. Jewiss, Basingstoke 2007, s. 283.

18 Tamże.

19 Zob. np. S. Arle, Toxic scandal in mozzarella country, "The Guardian" 14 October 2004. Wersja online: <http://www.guardian.co.uk/world/2004/oct/14/italy.sophiearie> [dostęp 5 maja 2009]. 
lirowych. Kiedy w ziemi nieopodal znaleziono dużo tonerów z drukarek, z których do ziemi wyciekały substancje zawierające rakotwórczy sześciowartościowy chrom, sprawa nielegalnego składowania tych bankowych odpadów zyskała specjalny status. Prokuratorskie dochodzenie prowadzone z oskarżenia publicznego pod kryptonimem Madre Terra doprowadziło do głośnego procesu, który odbył się w 2006 roku ${ }^{20}$.

Niekontrolowane gromadzenie śmieci przekształca krajobraz. Formowane są „nieistniejące wcześniej wzgórza”, a „wszystkie zastane szczeliny i doły zostają wypełnione"21. Cyklem rządzi przerażająca logika grabieżczej ekonomii: kup ziemię, zrób kamieniołom lub wydobywaj piasek, zdobądź dotację na rekultywację i oczyszczenie terenu, a wydrążone miejsca wypełnij śmieciami. Wszędzie, gdzie tylko jest lub mogłaby być pusta przestrzeń - w opróżnionych zbiornikach pod zamkniętymi stacjami paliw czy w niezamieszkałych domach na prowincji - magazynuje się odpady. W jednym z proekologicznych dokumentów filmowych Biùtiful Cauntri ${ }^{22}$ przedstawiony został skrajny przypadek składowania niekończącej się góry śmieci na pasie pomiędzy dwoma nitkami autostrady.

Do często praktykowanych metod pozbywania się odpadów należy mieszanie ich $\mathrm{z}$ betonem lub asfaltem, a także rozdrabnianie, wzbogacanie szczątkami organicznymi i rozprowadzanie jako kompost na użytkach rolnych w całym kraju ${ }^{23}$. Niepodzielne sprawowanie kontroli nad wywozem i utylizacją odpadów w Neapolu i okolicach każdego roku przynosi Camorrze dochód większy niż cały zysk generowany przez koncern Fiata. Jedną $\mathrm{z}$ konsekwencji takiego biegu rzeczy jest odnotowywane w regionie zwiększenie liczby zachorowań ludzi i zwierząt. Najwyraźniej widoczne jest to w okolicach Caserty, Acerro i innych miejscowości na przedmieściach Neapolu, w których gwałtownie wzrosła zachorowalność na raka, zwłaszcza raka wątroby, białaczkę i rozmaite chłoniaki ${ }^{24}$.

${ }^{20}$ R. Saviano, Gomorrah: Italy's Other Mafia, dz. cyt., s. 286.

21 Tamże, s. 285.

22 E. Calabria, A. d'Ambrosio, P. Ruggiero, Biùtiful Cauntri (DVD), Milan 2008.

${ }^{23}$ Podobne techniki stosowane były w Anglii, gdzie w połowie lat dziewięćdziesiątych pozbywano się tak popiołów zawierających duże ilości dioksyn z pieców firmy Byker, spalających odpady w okolicach Newcastle, a do sierpnia 2000 także przez przedsiębiorstwo London Waste. Zakład Byker pozbył się ponad 2000 ton niezneutralizowanych, wysokotoksycznych pyłów, rozprowadzając je po parkach, działkach i ścieżkach; popiół z pieca Edmonton włączano w materiał do budowy dróg, parkingów i do produkcji 15000 ton cegieł i pustaków (to liczba wystarczająca do zbudowania około 3400 domów). Zob. np. R. Girling, Rubbish! Dirt on our hands and crisis ahead, London 2005 i I. Sinclair, London Orbital, Harmondsworth 2003.

${ }^{24}$ K. Senior, A. Mazza, Italian "Triangle of Death" linked to waste crisis, "The Lancet" (Oncology), vol. 5, September 2004, s. 525-527. 
We Włoszech i innych państwach Europy Zachodniej składowana jest tylko część tego, czego ogółem pozbywają się międzynarodowe korporacje. Trafigura ${ }^{25}$ z zadziwiająca lekkomyślnością rozrzuca toksyczny muł w Abidżanie na Wybrzeżu Kości Słoniowej, a Shell beztrosko przyczynia się do dewastacji delty rzeki Niger. Włoska przestępczość zorganizowana pozbywa się odpadów poprzez międzynarodową sieć zbudowaną na zależnościach wypracowanych do przemytu i rozprowadzania narkotyków. Łatwo przychodzi jej prowadzenie nielegalnych interesów z rządzącymi krajami Trzeciego Świata. Powiązania przebiegają przez państwa Europy Środkowo-Wschodniej (zwłaszcza Rumunię, gdzie niedawno znaleziono dowody na zatopienie radioaktywnych odpadów w wodach Morza Czarnego), Albanię, Chiny czy Kostarykę, a przede wszystkim Afrykę (Mozambik, Nigerię, Somalię i in.), na terenie których pozbywa się śmieci zarówno na lądzie, jak i w morzu. Znane są liczne przypadki zrzucania odpadów w obciążonych beczkach bezpośrednio ze statków, a nawet celowego zatapiania całych okrętów z ładowniami wypełnionymi śmieciami (przy czym czymś normalnym są następujące potem roszczenia do ubezpieczających je firm). Wiadomo, że (podobnie jak przy wschodnich wybrzeżach Afryki, tylko na mniejszą skalę) statki z beczkami pełnymi radioaktywnych substancji pogrążano w Morzu Śródziemnym w okolicach Kalabrii.

Tsunami z grudnia 2004 wyrzuciło na brzegi Somalii setki nielegalnie zatopionych, rdzewiejących beczek $\mathrm{z}$ odpadami zawierającymi substancje radioaktywne i metale ciężkie. Raport ONZ dotyczący tego przypadku (którego wnioski potwierdzane są także przez inne źródła) wskazywał, że winny jest włoski świat przestępczy. Pojawiające się ostatnio oświadczenia somalijskich „piratów” wskazują, że część pieniędzy otrzymywana przez nich jako okup za porwane statki wykorzystywana jest $\mathrm{w}$ celu finansowania prac mających prowadzić do uprzątnięcia wybrzeża ze śmieci, które przez ostatnie 20 lat były porzucane tam przez ekomafię. Ma to pomóc w odzyskaniu tych wód dla rybołówstwa.

Rozrost gór śmieci prowadzi do zwiększenia groźby katastrofalnych osunięć ziemi, także spod stóp ludzi. „Wystarczy, aby jedna puszka, zużyta opona, nadtłuczona flaszka stoczyła się na stronę Leonii, a grad butów nie do pary, kalendarzy z minionych lat, uschłych kwiatów pogrąży miasto $\mathrm{w}$ jego własnej, na próżno odpychanej przeszłości, przemieszanej z przeszłością sąsiednich miast, na koniec oczyszczonych"26. Miasta gotowe są przenieść się na nowe terytoria, wyrównane przez buldożery, które

25 Trzecie co do wielkości globalne przedsiębiorstwo handlujące produktami ropopochodnymi i metalami nieżelaznymi (przyp. tłum.).

26 I. Calvino, Niewidzialne miasta, dz. cyt., s. 97. 
zdolne są do wymazania każdego śladu po Leonii. Odzyskana przestrzeń zawłaszczana jest przez ich własnych zamiataczy ulic, tymczasowo „oddalających nowe śmietniska"27.

\title{
"Mówią na podwórku śmieci"28
}

\author{
Największym moim marzeniem było użycie materii, \\ do której nie przywiazuje się żadnej wagi - śmieci, bzdur, odrzutów - \\ w taki sposób, żeby ich konfiguracja i kontekst sprawity, \\ $\dot{z} e$ „zaśpiewaja” własnym głosem. \\ To byt pomyst na stworzenie czystej dramaturgii, \\ na sztukę, która pozwala na rozwój 29.
}

Od czasu dadaistycznych i kubistycznych kolaży czy surrealistycznych détournement d'objets trouvés różne rodzaje materii i rzeczy porzucanych jako śmieci były przygarniane przez sztukę. Działanie w jej obszarze prowadzić może ku ich recyklingowi w nieskończonej liczbie dzieł i działań. Tekst ten nie jest najlepszym miejscem, by wymieniać artystów, którzy przez ostatnie pół wieku włączali odpady bądź odrzucanie w zakres swojej twórczości. Nie będę więc szerzej zajmował się tu Oxidation Paintings Andy'ego Warhola ${ }^{30}$, Merda d'artista w puszce sygnowanej przez Piera Manzoniego (1961), działalnością Michaela Landy’ego, który podczas publicznych wystąpień zaproponował odwrócenie procesu produkcji artystycznej - demontaż, rozbiórkę, zniszczenie i usunięcie odzyskanego w ten sposób surowca (Breakdown, 2001). Nie będę też skupiał się na postaci Gavina Turka, który w roku 2004 metaliczną farbą poma-

27 Tamże, s. 98.

28 "Says the junk in the yard” („Mówia na podwórku śmieci”) to fraza śpiewana przez chórki w piosence Junk Paula McCartneya (1968): "Buy buy, says the sign in the shop window / Why, why, says the junk in the yard” („Kup, kup, woła znak w sklepowym oknie / po co, po co, mówią na podwórku śmieci”). Rozważane było włączenie tego utworu do tzw. Białego albumu Beatlesów, jednak został on odrzucony i dopiero po dwóch latach, jakby poddany recyklingowi, pojawił się w solowym albumie McCartneya. Pierwsza część cytowanej tu frazy z tej delikatnej krytyki konsumpcjonizmu użyta została w roku 2007 jako tytuł wystawy sztuki nawiązującej do problemu śmieci w londyńskiej Flowers East Gallery (zob. S.Ch. Dickson, Says the junk in the yard, dz. cyt.).

${ }^{29}$ T. Etchells, Doing Time, "Performance Research" September 2009, r. 14, nr 3, s. 76.

30 Warhol sikał na pokryte warstwą miedzi płótna, a uryna, przyspieszając proces utleniania, wywoływała na nich specyficzne i niepowtarzalne wzory. 
lował zestaw kubłów na śmieci, śpiwór należący niegdyś do osoby bezdomnej, pogniecione puszki po piwie, kontener na odpady i wypaloną zapałkę tak, że wyglądały niczym wykonane $\mathrm{z}$ brązu ${ }^{31}$. Zamiast opisywania tych i podobnych poczynań i działań artystycznych chcę zwrócić uwagę na grupę artystów, ich zachowań i dzieł, w których odpady nie tylko się pojawiają, ale mają fundamentalne znaczenie dla powoływanych znaczeń. Ich sztuka powiązana jest ze współczesnym krajobrazem - tym dosłownym, ale także tym, który rozumieć można jako krajobraz kulturowy. Znajdują się tu „artyści ziemi” (landartists's2), proekologiczni aktywiści, artyści konceptualni i krytyczni dowcipnisie, prowokujący tabloidy do formułowania nagłówków krzyczących na witrynach: „Ta sztuka to śmiecie!". Każda z wymienionych tu i podobnych im kategorii, przez jednoznaczną sugestię znaczeniową okazuje się raczej nieadekwatna do wielopłaszczyznowej wymowy praktyk wpisujących się w nie osób.

W 1975 roku, w amerykańskim mieście Leviston w stanie Nowy Jork, Alan Sonfist zrekultywował fragment wysypiska, na którym składowane były toksyczne odpady chemiczne. Rozpoczął od uprzątnięcia małego koła pośrodku zanieczyszczonego terenu, na które nawiózł żyzną, próchniczą glebę, tytułując to działanie Pool of Virgin Earth („Obszar Dziewiczej Ziemi”). W stworzonym przez artystę okręgu kiełkowały nasiona przyniesione przez wiatr, po pewnym czasie rozkwitły dzikie kwiaty i rozkrzewiły się większe rośliny. Flora w delikatny sposób przypominała o tym, co znajdowało się kiedyś w miejscu, w którym teraz miasto gromadziło swoje odpady - albo refleksem tego, czym może stać się ono w przyszłości, kiedy ludzie nie będą już go dewastować. Pool był częścią serii Time Landscapes („Krajobrazy Czasu”). Wszystkie działania proponowane w jej ramach przez Sonfista miały pokrzepiającą wymowę: powoływały utopijne krajobrazy, budując „publiczne pomniki” zjawisk natury. Mogły one przypominać o minionej przeszłości Ziemi, ale w tym samym

31 Przegląd taki może uwzględniać także artystów tak różnych, jak Pablo Picasso, Marcel Duchamp, Hans Belmer, Kurt Schwitters, Joseph Cornell, Robert Rauschenberg, Nancy Holt, Eva Hesse, Christian Boltanski, Anselm Kiefer, Gustav Metzger, Irving Penn, Peter Blake, Mark Dion, Richard Wentworth, Cornelia Parker, Ursula Biemann, Alastair Maclennan, Wolfgang Tillmans, Helen Chadwick, Sarah Lucas, David Shrigley czy Yao Lu. Komentarze dotyczące wystawy kubłów Gavina Turka The Golden Thread (2004), a także ekspozycji ośmiu kubłów „z brązu” (Pile), zob. M. Collings, False Identity, "New Statesman" 16 February 2004. Wersja online: <http://www.newstatesman.com/2004021 60034> [dostęp 2 lutego 2010].

32 Wydaje się, że w tym miejscu zamiast używanej powszechnie w języku polskim nazwy „sztuka ziemi” bardziej odpowiednim pojęciem na określenie omawianej grupy twórców byłaby „sztuka krajobrazu” (przyp. tłum.). 
stopniu miały także szansę stać się cichym przypomnieniem o jej możliwej przyszłości ${ }^{33}$.

Agnes Denes to artystka i aktywistka, która w 1982 roku uprawiała pole pszenicy na Dolnym Manhattanie, w centrum Nowego Jorku. Dwie przecznice od bliźniaczych wież World Trade Centre i Wall Street, w cieniu Statui Wolności, pracująca pod jej przewodnictwem grupa ochotników oczyściła fragment opuszczonego terenu z kamieni i śmieci ${ }^{34}$. Następnie nawieziono na niego wywrotki gleby, pokrywając cały obszar jej dwuipółcentymetrową warstwą. W ręcznie wykonanych 285 bruzdach posiano nasiona. Konieczne było stworzenie systemu nawadniającego, regularne sprzątanie i doglądanie uprawy, odchwaszczanie i zraszanie. Po czterech miesiącach troskliwej pielęgnacji i stopniowych transformacjach kolorystycznych całego pola (od brązu, przez zieleń do barwy bursztynu) żniwa przyniosły ponad 500 kilogramów mąki. Wkrótce potem teren wrócił do miejskiego rytmu, narzucanego przez ekonomikę intensywnego rozwoju metropolii: wybudowano na nim luksusowe apartamenty. Kiedy autorka tej efemerycznej instalacji-działania po latach zastanawiała się nad swoim Polem pszenicy (Wheatfield), potwierdziła zamiar krytycznego odniesienia się do wykorzystanego przez siebie miejsca (skrajnie zurbanizowana tkanka miejska), jak też nostalgiczną tęsknotę za utopią: „W ten sposób reprezentowany był nie tylko pokarm, ale i energia, handel, światowy rynek, ekonomia w odniesieniu do złego zarządzania ziemią i głodu. To było wtargnięcie na teren bastionu, konfrontacja $\mathrm{z}$ twierdzą Zaawansowanej Cywilizacji. Dla kogoś, kto tam wówczas trafił, mógł to być jednak po prostu mały rajski ogród wyobraźni z dzieciństwa, Shangri-la, gorące letnie popołudnie poza miastem, spokój, zapomniane wartości, prosta przyjemność”35.

W późnych latach sześćdziesiątych, w opisie projektu pracy zatytułowanej Wyspa tłuczonego szkła (Island of Broken Glass), którą rozumieć można jako współczesną praktykę „głębokiej ekologii” (deep ecology), amerykański artysta krajobrazu Robert Smithson zasugerował, by mała wyspa Miami Islet, znajdująca się w granicach portu Vancouver, została pokryta tłuczonym szkłem. Po bardzo długim czasie, w rezultacie działania naturalnej erozji doszłoby do daleko idącej degradacji i entropii frag-

33 A. Sonfist, Natural Phenomena as Public Monuments [1968], [w:] Land and Environmental Art, eds J. Kastner, B. Wallis, London 1998, s. 257-258.

34 Zagospodarowany wówczas teren rozciągał się na obszarze mniejszym niż hektar, którego wartość szacowana była wówczas na 4,5 mld dolarów (przyp. tłum.).

35 A. Denes, Wheatfield: A Confrontation [1982], [w:] Theories and Documents of Contemporary Art: A Sourcebook of Artists' Writings, eds K. Stiles, P. Selz, Berkeley 1996, s. 544. 
mentów kruszcu na coraz mniejsze drobiny, które w końcu, w całej swojej wielości i różnorodności, znów stałyby się piaskiem. Ta radykalna propozycja, ucieleśniająca stwierdzenie „z prochu powstałeś i w proch się obrócisz", napotkała zaciekły opór lokalnych ekologów, przekonanych o złym wpływie takiego postępowania na okoliczną przyrodę. Projekt nigdy nie został zrealizowany. W swojej ripoście Smithson stwierdził: „Wyspa nie ma na celu ocalić czegokolwiek ani kogokolwiek, a po prostu pokazać, jak rzeczy się mają" 36 .

W innym miejscu artysta pisał o swoim pomyśle na Muzeum Porzuconych Ideologii: „W muzeum tym każdy znajdzie eksponaty pordzewiałej Filozofii, a w szklanych gablotach nieznane bryły czegoś, podpisane jako Estetyka. Można przejść się przez zrujnowane korytarze i zobaczyć pozostałości Wspaniałości i Chwały"37.

Podobny wydaje się zamysł rozkosznie dowcipnej, encyklopedycznej wystawy według pomysłu Petera Greenawaya 100 Objects to Represent the World („100 rzeczy reprezentujących świat”) z 1992 roku, która nawiązywała do koncepcji niegdysiejszych Wunderkammer. Wśród eksponatów znalazły się buty, pliki gazet, metrowy sześcian wypełniony ziemią, cegły, owoce i warzywa pozostawione rozkładowi na sto lat, wypchana krowa, żelazna klatka więzienna, setka kompletnych sztucznych szczęk, powalone drzewo, rozbity samolot, zawalona kolumna, fragmenty antycznej rzeźby, trumna, konny karawan, kupka kurzu zebrana w domach na przedmieściach Wiednia czy czerwono-czarne zsypy wymontowane z budynków mieszkalnych. Tytuł eksponatu numer 50 na tej liście to Rubbish („Śmieci”). Został on umieszczony także na grzbiecie katalogu wystawy, co sugerowało, że to podtytuł całej tej muzealnej mapy krajobrazowej kulturowych szczątków ${ }^{38}$.

Świetny film Agnès Vardy Les Glaneurs et la Glaneuse (Zbieracze $i$ zbieraczka, 2000) dokumentuje przeróżne praktyki zbieractwa praktykowane we współczesnej Francji. Ukazuje „drobne gesty” (gestes modestes) miejskich zbieraczy ulicznych, poszukujących jedzenia w sklepowych śmietnikach i odzyskujących resztki zostawiane na placach targowych. Portretuje ludzi pozyskujących owoce i warzywa pozostawione po zbiorach na terenach uprawnych albo odrzucone jako niespełniające unijnych standardów kształtu i wielkości. Zbieranie pokłosia określane jest tu jako „pęk możliwości”39. To pomysłowe, świadczące o wyobraźni i twórcze wy-

${ }^{36}$ R. Smithson, The Collected Writings, ed. J. Flam, Berkeley 1996, s. 197.

37 Tamże, s. 98.

38 P. Greenaway, 100 Objects to Represent the World, Stuttgart 1992.

39 A. Varda, The Gleaners and I [2000] i Les Glaneurs et la Glaneuse - deux ans après [2002], Artificial Eye DVD 2009. 
korzystanie tego, co daje życie, ale także manifestacja opozycyjnej etyki i mikropolityki, które utrzymywane są dzięki nieformalnym sieciom powiązań i oddolnej komunikacji społecznej.

Wielu napotkanych przez Vardę ludzi to bezdomni i bezrobotni; część stanowią artystyczni outsiderzy, często również używający odpadków, resztek i śmieci w swojej pracy. Alain F., bezrobotny wegetarianin biegający w maratonach, za dnia zbiera nadające się do jedzenia rzeczy pozostawione na placach targowych, a wieczorami w swoim szałasie uczy emigrantów czytania i pisania. Przybyły z Afryki Solomon odnajduje i naprawia porzucone sprzęty AGD (lodówki, kuchenki itp.), żeby je sprzedać lub podarować któremuś ze swoich ubogich krewnych czy przyjaciół. Varda przyznaje, że jej działania również określić można jako gromadzenie „obrazów, wrażeń, emocji”40, dokonywane za pośrednictwem małej kamery wideo. Ale skupia się także na poszukiwaniu rzeczy materialnych, kolekcjonując np. ziemniaki, których kształt przypomina serce. Ich sadzenie, kiełkowanie i rozwój (lub stopniowy rozkład) zostają udokumentowane jako część cichej medytacji artystki na temat konsumpcji i pozostawianych po niej resztek, dotyczącej naturalnego obiegu materii organicznej i współczesnej moralności.

Scena otwierająca dokumentalny film Jennifer Baichwal pt. Edward Burtynsky: Manufactured Landscapes (2007) zawiera ośmiominutowe ujęcie $\mathrm{z}$ kamery prowadzonej $\mathrm{w}$ tempie piechura wzdłuż - na pierwszy rzut oka nigdy niekończącej się - ściany hali fabrycznej gdzieś w Chinach. Wrażenie jest podobne do tego wywoływanego przez niezwykłe, wielkoformatowe zdjęcia Burtynsky'ego. Przez ostatnie 30 lat dokumentował on przemysłowe krajobrazy, eksponując ich niesamowite wprost detale. Jak świat długi i szeroki fotografował miejsca naznaczone bliznami fabryk, cięciami inżynieryjnych konstrukcji (jak Tama Trzech Przełomów w Chinach), ranami kopalni, kamieniołomów, rafinerii, linii kolejowych, złomowisk statków, wrzodami pozostawionych odpadów lub ropiejących ran ich niekontrolowanego przerobu. Ukazana w jego pracach skala ludzkiej ingerencji w środowisko przeraża. Produkcja i konsumpcja, wraz z nadmiarem produktów ubocznych, pozostawiają wyraźne ślady na powierzchni Ziemi.

Burtynsky, podobnie jak i wielu innych fotografów, uwidacznia ukrytą wzniosłość przemysłu i jego złowrogich pozostałości, a jego twórczość może być traktowana jednoznacznie jako zaproszenie do refleksji. To jeden $\mathrm{z}$ kronikarzy apokalipsy środowiska naturalnego ${ }^{41}$, dokonującej się

40 Tamże.

${ }^{41}$ Określenie to opisuje również artystów, takich jak: Richard Misrach, Robert Polidori, Naoya Hatakeyama, Sophie Gerrard, Mikhael Subotzky i David Hughes. 
za sprawą rozwoju przemysłu i coraz większych potrzeb technologicznych ludzkości. Sam Burtynsky komentował jednak swoje prace w nieco innym duchu: „Obrazy te pomyślane zostały jako metafora jednego z dylematów, które stały się powszechne współcześnie, w naszym życiu; zachęcają do negocjacji i poszukiwania dialogu pomiędzy odczuciami przyciągania i wstrętu. Uwodzą, ale i wywołują lęk, uświadamiając nam, że efekty prowadzącego nas i odczuwanego nieprzerwanie pożądania (skądinąd dającego szansę na dobre życie) nie zawsze są przez nas uświadamiane. A świat cierpi, żebyśmy mogli osiągnąć, czego chcemy. Nasza zależność od natury, która zapewnia nam środki do życia i wynikająca z tego konieczność utrzymania przy życiu planety, stawia nas w niełatwym położeniu. Według mnie obrazy te uznać można za zwierciadło czasów, w których żyjemy" 42 .

Podczas czterdziestego dziewiątego Biennale w Wenecji w 2001 roku Maurizio Catellan skonstruował replikę słynnego napisu HOLLYWOOD. Dużo większe od oryginalnych, dwudziestotrzymetrowe litery tworzące napis stanęły na wzgórzach otaczających rozległe wysypisko Bellolampo w okolicy Palermo. Praca stała się rodzajem ironicznej halucynacji - pomnikiem Sycylii prezentowanej w amerykańskich filmach gangsterskich, ale też specyficznym hołdem dla symbolu poddanego przemieszczeniu. W wywrotowym połączeniu wysypiska i zbiorowego wyobrażenia na temat fabryki snów praca ta krytycznie wpisuje Palermo, wraz z jego śmieciami, w scenografię filmowej parodii. Koncepcja Catellana zawarła $\mathrm{w}$ sobie wiele nawiązań kontekstowych dotyczących konstruowania (i niszczenia) kształtów, wyglądów, pragnień - często związanych z mitycznymi opowieściami o sławie lub marzeniami otarcia się o nią (podobno w okolicy gruchnęła wieść, że napis był częścią scenografii do filmu z Sylvestrem Stallone). Catellan zaprosił sporą grupę międzynarodowych krytyków, kuratorów, marszandów, kolekcjonerów i innych VIP-ów, którzy w dniu otwarcia instalacji opuścili Wenecję. Artystyczny prowokator zaproponował popołudniowy lot na koktajl party, na którym pełen smakołyków elegancki bufet postawiono na rozgrzanym śmietnisku, w cieniu napisu HOLLYWOOD. Artysta filmował konsumujących gości, którzy chętnie pozowali mu w towarzystwie pracowników wysypiska. Stali się oni nieświadomymi dodatkami, statystami włączonymi w akt tworzenia sztuki krytycznej, która w zdecydowany sposób zaprzecza obowiązującym prawidłom rządzącym rynkiem sztuki.

42 J. Baichwal, Edward Burtynsky: Manufactured Landscapes (DVD), London 2007. 


\title{
Fresh Kills: miejsce upamiętnienia
}

\author{
Jesteśmy śmieciami, niemodnymi i niepożądanymi. \\ Wyrzucani na mokry bruk i pozostawiani tam na dtugie tygodnie, \\ niczym złowrogie ostrzeżenie. Trwamy w oczekiwaniu, \\ że zmienimy się $w$ dzieła sztuki. Nikt za to nie ptaci. To mój osobisty wybór, \\ by utożsamiać się z resztkami w miejscu, \\ które wypowiedziało wojnę wszystkim tym, \\ którym brak przekonania do zbierania i powtórnego użycia, \\ a którzy gotowi sa wznosić kosztowne pomniki swojej nieobecnej pamięci ${ }^{43}$
}

Od ponad trzydziestu lat artystka Mierle Laderman Ukeles jest rezydentką przy Wydziale Oczyszczania Miasta Nowy Jork (NYC Department of Sanitation). W tym czasie zorganizowała wiele spektakularnych projektów w przestrzeni publicznej, skupiając się na problemach związanych $\mathrm{z}$ organizacją utylizacji odpadów. Początkowo działała samozwańczo, nie dysponujac funduszami ani wynagrodzeniem. W swoich działaniach łaczy problemy społeczne i państwowe, środowisko i politykę. Praca Touch Sanitation (Dotyk Śmieciarza 1978-1984) to dokumentacja jej spotkań z osobami oczyszczającymi miasto. W czasie nieco dłuższym niż jedenaście miesięcy uścisnęła ręce ponad ośmiu i pół tysiąca pracowników zajmujących się śmieciami w Nowym Jorku, dziękując im za ich wysiłek. Była to odpowiedź na społeczną marginalizację ludzi wykonujących zawód śmieciarza i podjęcie próby rewaluacji ich funkcji. Obecność ciepłych, empatycznych gestów podczas spotkań ukazywała przy okazji rolę relacji międzyludzkich w wytwarzaniu przyjaznego mikroklimatu nawet w przestrzeni wielkomiejskiej.

Inna praca tej samej artystki - Flow City (1983-1990) ujawniła na użytek publiczności codzienną praktykę radzenia sobie $\mathrm{z}$ odpadami w Nowym Jorku i skalę tego przedsięwzięcia. Jej najważniejszą częścią było wejście widzów na teren rozległego portu transportowego na Manhattanie, gdzie śmieci przeładowywane były z ciężarówek na barki, by rzeką Hudson popłynąć ku wysypisku. Realizacja projektu zakładała współpracę artystów, architektów, naukowców, ekologów; pociągała za soba stworzenie platform obserwacyjnych i szklanej kładki nad śmieciami, umieszczenie monitorów, na których transmitowany był na żywo obraz rzeki (po której poruszają się barki ze śmieciami), obraz z miejsca przerobu surowców wtórnych i z wysypiska. W ten sposób Ukeles umożliwiła wielu osobom dostęp do miejsc i działań, które na co dzień pozosta-

${ }^{43}$ I. Sinclair, Hackney, That Rose-Red Empire: A Confidential Report, London 2009, s. 7. 
ją ukryte - niedostępne i niewidzialne. Dzięki niej zyskali okazję do refleksji i zastanowienia nad kruchą równowagą ekologiczną.

Od 1989 Ukeles pracowała także w obszarze wysypiska Fresh Kills na zachodnim brzegu Staten Island. $\mathrm{Na}$ to największe wysypisko świata, działające od roku 1948 do marca 2001 (kiedy oficjalnie zostało zamknięte), każdego dnia zwożono ponad 25000 ton odpadów regularnie wydalanych przez Nowy Jork. Zgodnie z opinią Urzędu Zarządzania Ziemią (Centre for Land Use Interpretation) Fresh Kills stworzyło „nowy rodzaj krajobrazu, który pozostaje w ciągłym ruchu, dzięki swobodnemu odgazowywaniu, wyciekom płynów i mieszaniu się materii. To pokryty cienką warstwą ziemi, falujący, nasączony wilgocią, pełen energii bioreaktor rozkładu przetworzonej materii organicznej44. Po półwieczu działania i intensywnego rozwoju wysypisko zostało nagle zamknięte $\mathrm{z}$ powodu przeładowania i nadmiernego rozrostu, a także wskutek nasilających się lokalnych protestów. Rozciągające się na niemal 900 hektarach (obszar będący mniej więcej trzykrotnością tego, który zajmuje Central Park) Fresh Kills zaczęło stanowić zagrożenie dla ruchu powietrznego. Obszar ten to dzisiaj jedno z najwyższych wzniesień na całym wschodnim wybrzeżu Stanów Zjednoczonych. Jedna $\mathrm{z}$ jego hałd, oddalona o zaledwie kilka mil na północ od Statui Wolności, przerosła ją o ponad 20 metrów.

13 września 2001 roku największa część Fresh Kills (sekcja zachodnia 1/9 - ok. 200 hektarów) została ponownie otwarta jako miejsce specjalnego przeznaczenia na polecenie FBI, CIA i nowojorskiej policji - instytucji, które zaczęły jej ponowne użytkowanie. To tutaj złożono i badano 1,8 miliona ton gruzu i innych szczątków wież World Trade Centre po atakach terrorystycznych 11 września. Uśpione przystanie i stacje przeładunkowe wraz z kotwiczącymi przy nich barkami znów, na kilka dni, zostały zmobilizowane. W opublikowanym wiosną 2002 artykule Ukeles pytała o aktualną wymowę Fresh Kills, zasilonego szczątkami bliźniaczych wież: „Jakie znaczenie ma to miejsce dzisiaj?”45. W jej opinii wysypisko jest rodzajem, powstającej zbiorowym wysiłkiem, wielkomiejskiej konstrukcji ziemnej: „pięćdziesięcioletnią rzeźbą wykonaną przy współudziale nas wszystkich, złożoną z czterech wzgórz zbudowanych ze 115 milionów metrów sześciennych nierozróżnialnych, nienazywalnych, bezwartościowych odpadów, których materia - przemieszana i ujednolicona - została pozbawiona tożsamości”46. W wyniku rozłożenia na powierzchni

44 CLUI, Fresh Kills: considering New Amsterdam's mountain of life and death, <http://www.clui.org/lotl/v22/v22a.html> (tekst z roku 2001) [dostęp 5 lutego 2010].

45 M.L. Ukeles, It's about time for Fresh Kills, "Cabinet" 2002, nr 6 ("Horticulture"), Spring 2002, s. 20. Wersja online na stronie internetowej Cabinet: <http://www.cabinet magazine.org/issues/6/freshkills.php> [dostęp 1 lutego 2010].

46 Tamże. 
tego gruzu, a wraz z nim "szczątków i kurzu” pochodzącego z „tysięcy nieodnalezionych, spopielonych istnień ludzkich”, powstał „[...] pomnik albo raczej cmentarzysko. Cokolwiek to jest, powinno być traktowane na zupełnie nowych zasadach wypracowanych w ramach umowy społecznej. Pomieszanie mikroskopijnych fragmentów ciał i śmieci przełamuje tabu poprzez akt świętokradczego zjednoczenia. Trzeba o nim przypominać, konieczna jest bowiem gruntowna zmiana, świadoma kreacja nowego zwyczaju społecznego, który wpłynie na język określający to i podobne mu miejsca. Podkreślać warto znaczenie każdej drobiny pyłu i traktować ją z szacunkiem, ponieważ jej pochodzenie wiązać się może z jedną z osób, które zginęły. Stworzenie w tym miejscu zwyczaju, który zapisuje i przechowuje ich tożsamość, a nie zamazuje ją i jej pozbawia, to sposób na upamiętnienie zabitych w WTC. [...] Ta część z całości Fresh Kills musi uzyskać podwójne znaczenie: nienazywalnego uleczenia i nazwanego miejsca zmiany znaczeń utrwalonych w utartych określeniach"47.

Podczas dziesięciu miesięcy po 11 września, w warunkach, które zakładały zachowanie szczególnej delikatności i bezpieczeństwa, odbywał się proces intensywnego poszukiwania, ręcznego sortowania i analizy każdego fragmentu ruin. Odnaleziono ponad 50000 rzeczy osobistych i około 4000 fragmentów ludzkich ciał, które pozwoliły na identyfikację około 300 osób wcześniej nieodnalezionych lub niezidentyfikowanych. W czasie pisania tego tekstu trwają kolejne etapy tego procesu, angażujące specjalistyczne techniki z zakresu medycyny sądowej. Intensywność działań zwiększa się coraz bardziej, a w użyciu są coraz bardziej nowatorskie techniki, ponieważ około 1000 domniemanych ofiar nadal nie zostało zidentyfikowanych. Mimo to, a także wbrew serii pozwów wnoszonych przez domagające się dalszych badań rodziny ofiar, które zniknęły bez wieści, pochowane zostały duże ilości ludzkich prochów i popiołów, które uznane zostały za nierozpoznawalne.

W ostatnim czasie zainicjowany został wielki konceptualny projekt ekologiczny, mający przemienić całą rozległą przestrzeń dawnego wysypiska we Fresh Kills Park. Powstanie rozległy, ogólnie dostępny park krajobrazowy, który połączy różne biocenozy (łąki, ekoturystyczne moczary, lasy) i na terenie którego pojawią się liczne obiekty służące edukacji, rekreacji i wypoczynkowi. Pomysł tego rewitalizacyjnego zagospodarowania przestrzeni i skażonej ziemi pojawił się w 2006 roku jako propozycja architektów Field Operations, specjalistów od rekultywacji terenów poprzemysłowych. Autorzy oceniają czas jego pełnej realizacji na najbliższe trzydzieści lat ${ }^{48}$. Do dzisiaj dwie z czterech gór śmieci zostały pokryte

${ }^{47}$ Tamże.

48 Szczegóły realizacyjne i plany Field Operations w zakresie Fresh Kills Draft Master Plan znaleźć można na stronie Wydziału Urbanistyki Miasta Nowy Jork: <http://www. 
warstwą ziemi i ukryte pod nieprzepuszczalną, plastykową „geomembraną”, na której rozłożono tak zwane „czyste wypełnienie” z zawalonych konstrukcji WTC. W końcu całość przykryta będzie warstwą ziemi o grubości około 120 centymetrów, co umożliwi rozwój roślinności. Zainstalowane po bokach wzgórz urządzenia już dziś pozyskują metan, który trafia na rynek. Jego łączna wartość każdego miesiąca szacowana jest na około milion dolarów.

U podstaw tego nieskończonego palimpsestu, złożonego zarówno środowiskowo, jak i kulturowo, nieprzerwanie wyciekają toksyczne mazie (odcieki). Niebezpiecznymi produktami procesów rozkładu śmieci zajmuje się centrum oczyszczania. Tam usuwana jest część toksyn i pojawiający się w dużych ilościach amoniak, a ostatecznie trudne do utylizacji cząstki stałej materii zostają sprasowane w formie małych „ciastek” i zagrzebywane ponownie. Pozostała ciecz jest filtrowana i ponad 1100 litrów tej substancji jest zrzucanych każdej minuty do oczyszczalni Arthur Kill. W zachodniej części parku, blisko miejsca, gdzie spoczywają szczątki WTC, ma powstać pomnik o wymiarach zbliżonych do wymiarów leżących wież. Ma to być konstrukcja ziemna złożona z dwóch podłużnych kopców, na których zboczach znajdzie się rozległa łąka pełna dzikich kwiatów.

W powieści Underworld Don DeLillo portretuje zmarnowane życie swoich bohaterów. Aby metaforycznie opisać ich sytuację, przedstawia „jałowe nieużytki”, wśród których pojawiają się wizje olbrzymich wysypisk, takich jak Fresh Kills. Oddają one skalę ilości odpadów produkowanych przez współczesną kulturę konsumpcji. Wypracowana przez kapitalizm odpowiedź na problem śmieci wykorzystuje paradygmaty postmodernistycznej filozofii, nie szukając sposobu na powstrzymywanie wzrostu ich ilości (który powiązany jest z sukcesem ekonomicznym i na niego wskazuje), a jedynie zastopowanie ich ekspansji w pole widzenia. Bohater DeLillo - Nick Shay - pracuje w dziale zarządzania odpadami. Hamując osobisty oportunizm w przerobie i recyklingu śmieci, traktowanych jako towar w produkcji i pozyskiwaniu kapitału, Shay staje się „kosmologiem odpadków"49. W świecie powieści napotyka często „sceny z nowoczesnego średniowiecza": szybkie przybywanie odpadów kumuluje w miastach „piekielny smród każdej psującej się, kiedykolwiek wyrzuconej rzeczy"50. Zaduma literackiej postaci zyskuje nieco głębszy status,

nyc.gov/html/dcp/html/fkl/fkl4c.shtml>. Informacje o tym projekcie i wywiad z realizującym go dyrektorem Field Operations Jamesem Cornerem znajdują się w publikacji Jamesa Sullivana Wall-E Park, "New York Magazine" 23 November 2008. Wersja online: $<$ http://nymag.com/news/features/52452/> [dostęp 10 lutego 2010].

${ }^{49}$ D. DeLillo, Underworld, London 1998, s. 88.

50 Tamże. 
kiedy myśli ona o znaczeniu angielskich słów: „waste (odpadki) to interesujące słowo, którego losy prześledzić można przez staroangielski i staronordycki aż do łaciny, znajdując takie jego odpowiedniki i odmiany, jak empty (pusty), void (próżny), vanish (znikać) i devastate (niszczyć)"51.

Śmieci stały się alegorycznym obrazem Innego w kulturze. Ich potencjał znaczeniowy pozwala także na łączenie ich z „odkrywaniem symbolicznej figury towaru jako dobra jedynie pozornego" 52 , które prezentuje się jako ruina utopijnej obietnicy. W myśleniu o śmieciach ideałem byłoby zatem usunięcie ich z pola widzenia i pozbycie się wszelkich ich widocznych śladów, pozostawienie ich w „podziemiach”. Tak właśnie Nick Shay stara się postępować $\mathrm{z}$ własną przeszłością, zanieczyszczoną i niemal zapomnianą, która jednak „wycieka”, domagając się miejsca w pamięci. A przecież - jak we własnej powieści sugeruje Viktor Maltsev, jeden z wielu „teoretyków odpadów” - śmieci są „diabelskim bliźniakiem” kultury, a ich niesłychany upór trwania, nawet w ziemi, w której je pogrzebano, staje się tajemnym „spektaklem odwróconego biegu historii”53. To wyparta opowieść „zakazanych słów, sekretów trzymanych w wyczyszczonych grobowcach, wątków w połowie zapomnianych"54, które Shay wyobraża sobie jak „tuż obok” głównego nurtu życia „niezauważane sączą się do ziemi i w powietrze, a w zakamarkach kości przenikają do ich szpiku"55.

51 Tamże, s. 120.

52 J. Stallabrass, Trash, [w:] The Object Reader, eds F. Candlin, R. Guins, London 2009, s. 417.

53 Tamże, s. 791.

54 Wątek ten nawiązuje do koncepcji hyponoi wywiedzionej w Państwie przez Platona i opisanej przez Jamesa Hillmana: ,głęboki sens i podskórne znaczenie to antyczny sposób na określenie Freudowskiej treści utajonej. Jej poszukiwanie określane jest powszechnie jako chęć zrozumienia... poszukiwanie mocnych podstaw". J. Hillman, The Dream and the Underworld, New York 1979, s. 137).

55 J. Stallabrass, Trash, dz. cyt., s. 802-803. Zasadne jest porównanie „powrotu tego, co wyparte" z psychoanalitycznym zainteresowaniem „sekretnymi historiami”, zawierającymi przeoczane odpady powstające jako produkty życia psychicznego. Psychoanalityczne usiłowanie, by odgadywać rzeczy ukryte i zatajone na podstawie nieprzemyślanych czy niezauważonych szczegółów, wyciąganie ich niejako ze zbiorowiska odpadków naszych spostrzeżeń podobne jest praktyce zbieraczy Benjamina (zob. S. Freud, The Moses of Michelangelo, [w:] Art and Literature: Penguin Freud Library vol. 14, Harmondsworth 1985, s. 249-282). W filmie Agnès Vardy Les Glaneurs et la Glaneuse (2000) jednym ze starszych zbieraczy winnego pokłosia, z którym autorka przeprowadza wywiad, jest sławny psychoanalityk Jean Laplanche. Varda nie zdaje sobie jednak z tego sprawy aż do czasu, kiedy wraca, by zrobić kolejny film - Les Glaneurs et la Glaneuse - deux ans après (2002). Laplanche sugeruje w nim, że zarówno zbieracze pokłosia, jak i psychoanalitycy zwracają szczególną uwagę na to, co zwykle przeoczone, co wyrzucone poza mowę (dis- 
Śmieci, które dziś znaleźć można wszędzie, zostają poddane krytycznemu opisowi i recyclingowi poprzez radykalne („undergroundowe” $\mathrm{i}$ „outsiderskie”) praktyki artystyczne. Pośród wielu innych są wśród nich: Long Tall Sally Klary Sax, rekultywacyjne działanie w ramach sztuki krajobrazu na pustyni w Arizonie, na której spoczywają, niesamowite i wspaniałe, korpusy porzuconych samolotów B52 (działania te częściowo inspirowane były pracami Sabato Rodii - słynnymi Watts Towers - bricolages z odpadów wystawionymi w dzielnicy Watts w Los Angeles); działania Ismaela Muñoza AKA „Moonman 157” - undergroundowego graficiarza współpracującego z Runaways and Throwaways w aktach upamiętniania przeszłości na opuszczonych terenach południowego Bronxu, znanych jako „The Wall” (ściana) ${ }^{56}$; a także grupa rewolucyjnych artystów (Guerilla), próbujących wykraść śmieci J. Edgara Hoovera, długoletniego dyrektora FBI, by wykorzystać je potem w działaniach w ramach przygotowywanego performance art ${ }^{57}$. Próba ta wydaje się szczególnie znacząca $\mathrm{w}$ historycznej perspektywie, zwłaszcza jeśli pamięta się o tym, że Hoover legitymizował „nurkowanie w śmietnikach” jako metodę gromadzenia dowodów przez FBI.

Kiedy czytelnik powieści Underworld zbliża się do jej końca, dowiaduje się, że Nicka Shaya, kiedy ten wygląda z okna swojego domu w Phoenix, zadziwia „śmiertelność, która kurczowo trzyma się każdej rzeczy"58. Zaskakuje go także własna tęsknota za odkupieniem w ramach wiecznego powrotu „rzeczy, których używamy i których się pozbywamy”: „Spójrz, jak wracają do nas, opromienione jakby dostojną starością. [...] Wysypisko za drogą jest już zamknięte, jego pojemność została przekroczona; tylko gaz wydobywa się z wielkiego nasypu ziemnego; metan, który porusza powietrzem i ziemią, pogłębia aurę świętości. W wijącym się powietrzu cywilizacji zjaw wszystko jest bajką, pobłyskiem pustynnych ruin"59.

cours). Co zostaje upuszczone, a co się podnosi. Słowa, które pozostają poza codzienną mową, stanowią szczególną wartość dla psychoanalityków, ponieważ rzeczy, po które trzeba się schylić i zebrać osobno przedstawiają zawsze większą wartość niż te, które gromadzi się podczas żniw.

56 J. Stallabrass, Trash, dz. cyt., s. 813.

57 Ten wątek narracyjny zdaje się opierać po części na autoreferencyjnej stylistyce „samozwańczego śmieciologa” ('non-governmental garbologist') A.J. Webermana z jego datowanymi na lata sześćdziesiąte wielokrotnymi próbami śledzenia życia Boba Dylana (i innych celebrytów), poprzez przeglądanie ich śmieci. Rozpowszechnianie informacji o rzekomym skandalu zamierzone było w celu rekonstrukcji śladów, które oferowała „prawdziwa tożsamość” Dylana. Dużo pełniejsze informacje na ten temat znajdują się w książce J. Scanlana, On Garbage, London 2005, s. 147-153.

58 D. DeLillo, Underworld, dz. cyt., s. 804.

59 Tamże, s. 809-810. 


\title{
Gdzieś / tu (2): szukamy życia ${ }^{60}$
}

\author{
Obietnica, mówi o tym, że znów i jeszcze raz, \\ ze śmieci i rozrzuconego pierza, $z$ popiołów $i$ szczątków ciat, \\ narodzić się może coś nowego i pięknego ${ }^{61}$
}

Tak daleko / tak blisko, inny rodzaj morza, $w$ gtębi ladu. Podróżnicy przybywaja pojedynczo lub parami, czasem mała furgonetka pojawi sie w chmurze pytu, żeby wypluć z siebie stado niespokojnych ludzi. Ukrywaja sie przed słońcem, owijajac ciała płótnem. W podróz zabrali same najbardziej podstawowe rzeczy, ich torby sa lekkie. Dawno już pożegnali sie $z$ bliskimi. Ci, których pozostawili, nigdy nie powiedza, że ich syn, córka czy mąż „opuścili ich” czy „wyemigrowali”; odnosza sie do nich, traktujac jako „spalonych” - to ci, którzy spalili za soba przeszłość, przełamali odwieczne prawo wierności rodzinnej ziemi, opuszczając Afryke wiedzeni marzeniem o Europie.

$W$ miejscu spotkania na piaskach pustyni człowiek $w$ okularach stonecznych pokazuje im przygotowany materiat, który posłuży do zbudowania łodzi. Gdy tłumaczy zasady konstrukcji, kreśli znaki na piasku za pomoca trzymanego $w$ rękach kija. Przed nim leża olbrzymie sosnowe pnie. Na białym płótnie ktoś położyt sporo różnych śrub, wkrętów, dwa śrubokręty, młotek, kilka plastykowych baniaków, mogacych stać się materiatem na zbiorniki wypornościowe. Drewniana konstrukcja wyglada jak otwarta klatka piersiowa szkieletu wymartej bestii - jej wyblakte na słońcu, potem przysypane przez ruchomy piasek, a teraz znów ekshumowane / odkopane kości.

Wielu $z$ nich nigdy nie widziało morza. Majac różne wizje „łodzi” $w$ świadomości, rozpoczęli gromadzić się $w$ imię tej tajemniczej rzeczy, której zawierza życie i wszystkie swoje nadzieje. Ze stopniowo łaczonych fragmentów wyłania się zarys kadtuba. Czasami niski warkot wojskowego samolotu patrolujacego wydmy zagtusza ich puk-puk-pukanie. Chowaja sie wówczas pod siatkami maskujacymi albo kłada płasko na piasku, próbując stać się niewidzialnymi. Udają, że sq kolejnymi szczątkami, których petna jest pustynia.

Kiedy budowa dobiega końca, staja dokoła łodzi z mieszanymi uczuciami zadziwienia i przerażenia. Stłoczeni, by uniknać chłodu, nie śpiac, $w$ ciszy czekaja aż minie mrok, a wraz $z$ pierwszymi promieniami światła

60 Zob. The Maghreb Connection: Movements of Life Across North Africa, eds U. Biemann, B. Homes, Barcelona 2006.

61 J. Berger, Rumor, przedmowa do L. Tekin, Berji Kristin: Tales from the Garbage Hills, London 1996. 
zaciagaja swoja arkę ku morzu. Szukamy życia, mówią. Czas jego trwania trudno mierzyć, stosując miary słońca, faz księżyca czy cierpliwego pulsu oceanu, z jego przyptywami i odptywami, dawaniem i odbieraniem.

przetożyt Piotr Dobrowolski

\section{BIBLIOGRAFIA}

ARLE SOPHIE, Toxic scandal in mozzarella country, "The Guardian" 14 October 2004, wersja online: <http://www.guardian.co.uk/world/2004/oct/14/italy.sophiearie> [dostęp 5 maja 2009].

Baichwal Jennifer, Edward Burtynsky: Manufactured Landscapes (DVD), BFI, London 2007.

BaUman ZYGmunt, Życie na przemiat, przeł. T. Kunz, Wydawnictwo Literackie, Kraków 2004.

Beckett Samuel, Końcówka, [w:] tegoż, Dramaty. Wybór, przeł. A. Libera, Zakład Narodowy im. Ossolińskich, Wrocław 1999.

Benjamin Walter, Anioł historii. Eseje, szkice, fragmenty, red. H. Orłowski, przeł. K. Krzemieniowa i in., Wydawnictwo Poznańskie, Poznań 1996.

BERGER JOHN, “Rumor', preface to Latife Tekin”, Berji Kristin: Tales from the Garbage Hills, Marion Boyars, London 1996.

Calabria Esmeralda, D’Ambrosio Andrea, Ruggiero Peppe, Biùtiful Cauntri (DVD), BUR Senzafiltro/RCS Libri, Milan 2008.

Calvino Italo, Niewidzialne miasta, przeł. A. Kreisberg, Collegium Columbinum, Kraków 2004.

CLUI (2001), Fresh Kills: considering New Amsterdam's mountain of life and death, $<\mathrm{http} / / / \mathrm{www}$.clui.org/lotl/v22/v22a.html> [dostęp 5 lutego 2010].

Collings MatTHEw, 'False Identity', "New Statesman”, 16 February 2004, wersja online: <http://www.newstatesman.com/200402160034> [dostęp 2 lutego 2010].

DeLillo Don, The Power of History, "New York Times" 7 September 1997.

DeLillo Don, Underworld, Picador, London 1998.

Denes Agnes, Wheatfield: A Confrontation, (1982), [w:] Theories and Documents of Contemporary Art: A Sourcebook of Artists' Writings, eds K. Stiles, P. Selz, University of California Press, Berkeley 1996, s. 543-545.

Dickson Sam Chatterton, Says the junk in the yard (katalog wystawy), Flowers East/Creative London, London 2007 (stony nienumerowane).

Eтchells Tim, Doing Time, "Performance Research" September 2009, r. 14, nr 3, s. $71-80$.

Foucault Michel, Trzeba bronić społeczeństwa. Wykłady w Collège de France, 1976, przeł. M. Kowalska, Wydawnictwo KR, Warszawa 1998.

Freud Sigmund, The Moses of Michelangelo, [w:] Art and Literature: Penguin Freud Library, vol. 14, Penguin, Harmondsworth 1985, s. 249-282. 
GIRLING RICHARD, Rubbish! Dirt on our hands and crisis ahead, Eden Project Books/Transworld, London 2005.

Greenaway Peter, 100 Objects to Represent the World, Hatje, Stuttgart 1992.

Hillman James, The Dream and the Underworld, Harper \& Row, New York 1979.

KLIMA IVAN, Love and Garbage, trans. E. Osers, Vintage, London 1999.

Legambiente (2010), Illegal waste dumping archive, <http://www.legambiente.eu/ scienza/cdoc/elenco.php?keys=ecomafia\&x=0\&y=0> [dostęp 1 lutego 2010].

The Maghreb Connection: Movements of Life Across North Africa, eds U. Biemann, B. Homes, Actar, Barcelona 2006.

SAviano RoBerto, Gomorrah: Italy's Other Mafia, trans. V. Jewiss, Macmillan, Basingstoke 2007.

SCANLAN JOHN, On Garbage, Reaktion, London 2005.

SENIOR KATHRYN, MAZZA, AlFREDO, Italian “Triangle of Death" linked to waste crisis, "The Lancet" (Oncology), vol. 5, September 2004, 525-527.

Sinclair IAIn, Hackney, That Rose-Red Empire: A Confidential Report, Hamish Hamilton, London 2009.

SinCLAIR IAIN, London Orbital, Penguin, Harmondsworth 2003.

SMithson RoBert, The Collected Writings, ed. J. Flam, University of California Press, Berkeley 1996.

Sonfist Alan, 'Natural Phenomena as Public Monuments' [1968], [w:] Land and Environmental Art, eds J. Kastner, B. Wallis, Phaidon, London 1998, s. 257-258.

Stallabrass Julian, Trash, [w:] The Object Reader, eds F. Candlin, R. Guins, Routledge, London 2009, s. 406-424.

Sullivan JAMES, Wall-E Park, "New York Magazine" 23 November 2008, wersja online: $<$ http://nymag.com/news/features/52452/> [dostęp 10 lutego 2010].

Ukeles Mierle Laderman, It's about time for Fresh Kills, "Cabinet" nr 6 ('Horticulture'), Spring 2002, s. 17-20. Wersja online na stronie internetowej Cabinet: <http://www.cabinetmagazine.org/issues/6/freshkills.php> [dostęp 1 lutego 2010].

VARDA AGNÈs, The Gleaners and I [2000], i Les Glaneurs et la Glaneuse - deux ans après [2002], Artificial Eye DVD 2009. 